\title{
PENGARUH PENGGUNAAN KOSMETIK TERHADAP ACNE VULGARIS PADA REMAJA PUTRI KELAS I DAN KELAS II SMA NEGERI 4 BANDA ACEH
}

\author{
Mila Mauliza ${ }^{1}$, Elmiyati ${ }^{2}$, Andri ${ }^{2}$ \\ ${ }^{1}$ Mahasiswa Kedokteran Universitas Abulyatama Fakultas Kedokteran Umum \\ ${ }^{2}$ Dosen Fakultas Kedokteran Universitas Abulyatama
}

\begin{abstract}
The Influence Between The Use Of Cosmetics And Acne Vulgaris In Young Women Class I And Class II Of SMAN 4 Banda Aceh. Acne vulgaris is a common inflammatory condition in the polysebaceous unit that often occurs in adolescents and young adults. The exact cause of acne vulgaris is not yet known with certainty, but there are several factors that influence it such as genetic, hormonal, diet, cosmetic use, trauma, infection and psychological. The purpose of this study was to determine the effect of the use of cosmetics with acne vulgaris in adolescent girls class I and class II of SMAN 4 Banda Aceh. The study design used correlational design with cross sectional approach. The population in this study were 327 adolescents. The research sample uses simple random sampling of 180 teenagers. Data collection techniques used were approach and observation. Data analysis method used is chi-square. Research instruments using questionnaires, and physical examination (inspection). The independent variable of research is cosmetic use while the dependent variable is acne vulgaris. The results showed that the majority of students used cosmetics as many as $143(79.4 \%)$, and as many as $37(20.6 \%)$ students did not use cosmetics. Chi-square analysis results obtained $p$ value $=0.017<a(0.05)$ which means that there is an influence between the use of cosmetics with acne vulgaris in young women Class I and Class II at SMAN 4 Banda Aceh.
\end{abstract}

Keywords : Acne Vulgaris, Cosmetic Use, Teenager Girl

\begin{abstract}
Abstrak: Pengaruh Antara Penggunaan Kosmetik Dengan Acne Vulgaris Pada Remaja Putri Kelas I Dan Kelas II SMAN 4 Banda Aceh. Acne Vulgaris adalah suatu kondisi inflamasi umum pada unit polisebaseus yang sering terjadi pada remaja dan dewasa muda. Penyebab pasti acne vulgaris sampai saat ini belum diketahui secara pasti, namun terdapat beberapa faktor yang mempengaruhinya seperti genetik, hormonal, diet, penggunaan kosmetik, trauma, infeksi dan psikis. Tujuan penelitian untuk mengetahui pengaruh antara penggunaan kosmetik dengan acne vulgaris pada remaja putri kelas I dan kelas II SMAN 4 Banda Aceh. Desain penelitian menggunakan desain korelasional dengan metode pendekatan cross sectional. Populasi dalam penelitian ini sebanyak 327 remaja. Sampel penelitian menggunakan simple random sampling sebanyak 180 remaja. Teknik pengumpulan data yang digunakan adalah pendekatan dan observasi. Metode analisa data yang di gunakan yaitu chi-square. Instrumen penelitian menggunakan kuesioner, dan pemeriksaan fisik (inspeksi). Variabel independen penelitian adalah penggunaan kosmetik sedangkan variabel dependen adalah acne vulgaris. Hasil penelitian membuktikan bahwa sebagian besar siswi menggunakan kosmetik yaitu sebanyak $143(79,4 \%)$, dan sebanyak $37(20,6 \%)$ siswi tidak menggunakan kosmetik. Hasil analisis chi-square didapatkan nilai $p$ value $=0,017<a(0.05)$ yang berarti terdapat pengaruh antara penggunaan kosmetik dengan acne vulgaris pada remaja putri kelas i dan kelas ii sman 4 banda aceh.
\end{abstract}

Kata Kunci : Acne Vulgaris, Penggunaan Kosmetik, Remaja Putri 


\section{PENDAHULUAN}

Acne vulgaris adalah suatu kondisi inflamasi umum pada unit polisebaseus yang sering terjadi pada remaja dan dewasa muda (Simon, 2012). Penyakit ini tidak fatal, karena dapat sembuh dengan sendirinya. Namun, penyakit ini cukup merisaukan karena berhubungan dengan depresi dan ansietas, yang mana dapat dipengaruhi kepribadian, emosi, kesan diri dan harga diri, perasaan isolasi sosial, dan kemampuan untuk membentuk hubungan (Ahmed $\mathrm{S}$, Ahmed I, 2013).

Penyebab Acne Vulgaris (AV) sampai saat ini belum diketahui kepastiannya, tetapi banyak faktor yang mempengaruhinya. Beberapa faktor tersebut antara lain : genetik, hormonal, diet, penggunaan kosmetik, trauma, infeksi dan psikis (Hartadi, 2012). Acne Vulgaris merupakan penyakit peradangan menahun folikel pilosebasea, dengan gambaran klinis biasanya polimorfik yang terdiri atas berbagai kelainan kulit berupa : komedo, papul, pustul, nodul dan jaringan parut akibat kelainan aktif yang telah mengubah baik jaringan parut yang hipotrofik maupun yang hipertrofik. Penderita biasanya mengeluh adanya erupsi kulit pada tempat-tempat predileksi, yakni muka, bahu, leher, dada, punggung bagian atas dan lengan bagian atas (Fulton, James JR, 2010).

Penelitian oleh Tan dkk. Di Kanada pada tahun 2014 meneliti insiden penderita acne vulgaris pada beberapa ras yaitu Afrika Amerika $37 \%$, Hispanik 32\%, Asian 30\%, Kaukasian 24\% dan India 23\%. Pada penelitian tersebut didapatkan acne vulgaris derajat ringan $66 \%$, derajat sedang $33 \%$, derajat berat $<10 \%$. Insiden acne vulgaris berdasarkan jenis kelamin berbeda pada masing-masing penelitian. Shen dkk. Di Cina pada tahun 2011 mendapatkan prevalensi tertinggi pada perempuan sebesar $55 \%$.

Prevalensi Acne Vulgaris di kawasan Asia Tenggara terdapat 40$80 \%$ kasus sedangkan menurut catatan dari dermatologi kosmetika Indonesia terdapat $60 \%$ penderita acne vulgaris pada tahun 2006, 80\% pada tahun 2007 dan mencapai 90\% pada tahun 2009 (Susanto SD, 2010). Prevalensi acne vulgaris di Indonesia penelitian yang dilakukan pada siswa-siswi pada tahun 2013 di salah satu SMA (Sekolah Menengah Atas) di Medan terdapat $58 \%$ laki-laki dan $42 \%$ perempuan yang menderita acne vulgaris. Salim dkk. di Padang pada tahun 2016 meneliti mengenai profil acne vulgaris di Poliklinik Kulit dan Kelamin RSUP. DR. M. Djamil Padang 2013-2015. Diperoleh prevalensi acne vulgaris $2,86 \%$ dengan perbandingan perempuan dan laki-laki 1,5:1. Kelompok usia terbanyak ditemukan pada usia 15-24 tahun. ${ }^{5}$ Pada penelitian yang dilakukan oleh Arif Tirtana Putra tahun 2014 di Banda Aceh, dari 39 mahasiswi didapatkan bahwa angka kejadian acne vulgaris pada penggunaan kosmetik pembersih wajah minyak $50 \%$, padat $33.3 \%$, cair $25 \%$, dan krim $16.7 \%$ (Susanto SD, 2010).

Pada masa remaja, Acne Vulgaris lebih sering terjadi pada pria dari pada wanita. Sedangkan pada dewasa Acne Vulgaris lebih sering pada wanita dari pada pria. Acne tidak hanya terbatas pada kalangan remaja saja, $12 \%$ pada wanita $5 \%$ pada pria diusia 25 tahun memiliki acne. Bahkan pada usia 45 tahun, $5 \%$ pria dan wanita memiliki acne. Lesi awal acne mungkin mulai terlihat pada usia 8-9 tahun dan kurang dari $50-60 \%$ terdapat pada usia remaja. Puncak insiden pada usia 1417 tahun dijumpai pada wanita sedangkan usia 16-19 tahun pada pria (Cuncliffe WJ, 2010). Hampir 85\% anak SMA yng berusia antara 15-18 tahun, baik laki-laki maupun perempuan mempunyai berbagai derajat kelainan ini. Acne umumnya disebabkan oleh perubahan hormon dan peningkatan produksi sebum yang berlebihan (Harahap M, 2010). Akan tetapi, penggunaan kosmetik yang tebal dan berganti-ganti dapat menjadi salah satu faktor resiko terjadinya Acne Vulgaris. Kosmetik dapat menyebabkan 
timbulnya acne pada wanita dewasa, karena bahan yang digunakan bersifat komedogenik atau aknagenik, seperti: lanolin, petrolatum, beberapa minyak tumbuh-tumbuhan, butil stearat, merkuri, laurel alkohol dan asam oleat (NB Simpson, Cuncliffe WJ, 2012).

Salah satu faktor yang sering mempersulit penanganan acne adalah penggunaan kosmetik yang banyak bersifat komedogenik atau aknagenik. Bahan-bahan kimia yang ada dalam kosmetik dapat langsung menyebabkan acne dalam bentuk ringan terutama komedo tertutup dengan beberapa lesi papulopustul di daerah pipi dan dagu (Hartadi, 2010). Bahan-bahan kimia tersebut akan makin berbahaya ketika penggunanya berganti-ganti dari satu kandungan dengan kadar tertentu ke kandungan dan kadar yang lain seperti pada penggunaan kosmetik yang berganti-ganti. Karena kulit selalu harus melakukan penyesuaian dengan kandungan dan kadar baru (Harper JC, 2012).

Penderita acne, terutama wanita sering merasa sulit untuk meninggalkan kebiasaannya dalam memakai produk kosmetik. Penderita acne sering menginginkan produk kosmetik yang bisa dipakai tanpa menimbulkan atau memperburuk acnenya. Oleh karena itu, perlu diberikan edukasi yang baik mengenai bahaya penggunaan kosmetik yang berganti-ganti berupa cara efektif, mudah dilaksanakan dan murah dengan memakai pembersih dan pelembab yang non-abrasif dan menghindari pemakaian produk kosmetik yang menyebabkan timbulnya acne terutama kosmetik yang cenderung tebal dan menutup kelenjar sebasea kurang dianjurkan (Baumann L, Keri J, 2010).

Mengingat bahwa kejadian Acne vulgaris (AV) akibat pemakaian kosmetik sering terjadi di kalangan dewasa muda saat ini, maka penulis tertarik untuk melakukan penelitian yang berjudul Pengaruh Penggunaan Kosmetik Terhadap Acne Vulgaris Pada Remaja Putri SMA Negeri 4 Banda Aceh.

\section{METODE}

Penelitian ini menggunakan pendekatan analitik dengan desain cross sectional survey. Variabel independent meliputi penggunaan kosmetik, sedangkan variabel dependent yaitu acne vulgaris. Populasi dalam penelitian ini adalah remaja putri kelas I dan II IPA dan IPS SMA Negeri 4 Banda Aceh. Teknik pengambilan sampel menggunakan random sampling. Penelitian dilakukan di SMA Negeri 4 Banda Aceh Jl. T. Panglima Nyak Makam No.19 Kota Baru, Kuta Alam, Kota Banda Aceh. Penelitian dilakukan dari tanggal 20 Februari sampai 21 Februari 2019. Penelitian ini menggunakan data primer yang diperoleh dari pengisian kuesioner. Data dianalisis menggunakan analisis univariat dan bivariate, analisis univariat untuk melihat distribusi dan frekuensi variabel dependent dan independent, dan analisis bivariate untuk mengetahui hubungan antara variabel penggunaan kosmetik dan variabel acne vulgaris yang dianalisis dengan uji Chi-Squre $\left(X^{2}\right)$ dengan nilai $\mathrm{a}=0,05$, dengan ketentuan yang berlaku yaitu bila $p$ value $\leq a(0,05)$, maka ada hubungan yang bermakna antara variabel independent dan variabel dependent. Bila $p$ value $\geq a(0,05)$ maka tidak ada hubungan yang bermakna antara varibel independent dan variabel dependent.

Berisi jenis penelitian, waktu dan tempat penelitian, target/ sasaran, subjek penelitian, prosedur, data dan instrumen dan teknik pengumpulan data, serta teknik analisis data serta hal-hal lain yang berkaitan dengan cara penelitiannya.

\section{HASIL}

Berdasarkan hasil tabel 1 didapatkan responden paling banyak terdapat pada dua kelas yaitu kelas I IPA sebanyak 50 responden $(27,8 \%)$ dan kelas II IPA yaitu 50 responden $(27,8 \%)$. Berdasarkan hasil tabel 2 Didapatkan responden paling banyak memiliki klasifikasi acne vulgaris ringan sebanyak 71 responden $(39,4 \%)$. 
Tabel 1. Distribusi karakteristik berdasarkan kelas di SMA Negeri 4 Banda Aceh

\begin{tabular}{lcc}
\hline Karakteristik Kelas & Jumlah $(\mathbf{n})$ & Persentase (\%) \\
\hline Kelas I IPA & 50 & 27,8 \\
Kelas I IPS & 39 & 21,7 \\
Kelas II IPA & 50 & 27,8 \\
Kelas II IPS & 41 & 22,7 \\
\hline Total & 180 & 100 \\
\hline
\end{tabular}

Tabel 2. Distribusi frekuensi dan presentase klasifikasi acne vulgaris siswi

\begin{tabular}{lcc}
\hline $\begin{array}{c}\text { Klasifikasi Acne } \\
\text { Vulgaris }\end{array}$ & Jumlah (n) & Persentase (\%) \\
\hline Ringan & 71 & 39,4 \\
Sedang & 55 & 30,6 \\
Berat & 54 & 30,0 \\
\hline Total & 180 & 100 \\
\hline
\end{tabular}

Berdasarkan hasil tabel 3 didapatkan responden paling banyak menggunakan kosmetik yaitu 143 $(79,4 \%)$. Berdasarkan dari tabel 4. Persentase terdapatnya pengaruh antara penggunaan kosmetik yang tidak menggunakan kosmetik cenderung mendapatkan acne vulgaris ringan. Hasil uji statistik uji Chi-square dengan nilai signifikansi $p=0,017$ $(p<0,05)$ dan kekuatan chi-square $\left(x^{2}\right.$ $=0,037)$ menunjukkan bahwa terdapat hubungan antara penggunaan kosmetik terhadap acne vulgaris pada remaja putri SMA Negeri 4 Banda Aceh.

Tabel 3. Distribusi frekuensi dan persentase penggunaan kosmetik

\begin{tabular}{lcc}
\hline \multicolumn{1}{c}{$\begin{array}{c}\text { Penggunaan } \\
\text { Kosmetik }\end{array}$} & Jumlah (n) & Persentase (\%) \\
\hline $\begin{array}{l}\text { Menggunakan } \\
\text { kosmetik }\end{array}$ & 143 & 79,4 \\
$\begin{array}{l}\text { Tidak menggunakan } \\
\text { kosmetik }\end{array}$ & 37 & 20,6 \\
\hline Total & 180 & 100 \\
\hline
\end{tabular}

Tabel 4. Pengaruh penggunaan kosmetik dengan acne vulgaris pada remaja putri SMA Negeri 4 Banda Aceh

\begin{tabular}{|c|c|c|c|c|c|c|c|c|c|}
\hline \multirow{3}{*}{$\begin{array}{c}\text { Penggunaan } \\
\text { kosmetik }\end{array}$} & \multicolumn{9}{|c|}{ Klasifikasi Acne Vulgaris } \\
\hline & \multicolumn{2}{|c|}{ Berat } & \multicolumn{2}{|c|}{ Ringan } & \multicolumn{2}{|c|}{ Sedang } & \multicolumn{2}{|c|}{ Total } & \multirow[t]{2}{*}{$\mathbf{P}$} \\
\hline & $\mathrm{N}$ & $\%$ & $\mathrm{~N}$ & $\%$ & $\mathrm{~N}$ & $\%$ & $\mathrm{~N}$ & $\%$ & \\
\hline $\begin{array}{l}\text { Tidak } \\
\text { menggunakan } \\
\text { kosmetik }\end{array}$ & 8 & 21,7 & 18 & 48,6 & 11 & 29,7 & 37 & 100 & 00 \\
\hline $\begin{array}{l}\text { Menggunakan } \\
\text { kosmetik }\end{array}$ & 54 & 30,0 & 71 & 39,4 & 55 & 30,6 & 143 & 100 & \\
\hline Total & 62 & 51,7 & 89 & 88 & 66 & 60,3 & 180 & 100 & \\
\hline
\end{tabular}




\section{PEMBAHASAN}

Telah dilakukan penelitian di Sekolah Menengah Atas (SMA) Negeri 4 Banda Aceh. Responden adalah siswi SMA dengan usia 16-18 tahun yang bersedia mengikuti penelitian, dan tercatat sebanyak 180 responden. Dari 180 responden, terdapat 50 responden dari kelas I IPA, 39 responden kelas I IPS, 50 responden kelas II IPA, dan 41 responden dari kelas II IPS.

Berdasarkan tabel distribusi klasifikasi acne vulgaris didapatkan hasil bahwa responden paling banyak memiliki klasifikasi acne vulgaris ringan sebanyak $39,4 \%$ responden, sedangkan klasifikasi acne vulgaris berat $30,0 \%$ responden, dan acne vulgaris ringan $30,6 \%$ responden.

Berdasarkan tabel distribusi penggunaan kosmetik didapatkan hasil bahwa sebagian besar responden menggunakan kosmetik yaitu sebanyak $79,4 \%$. Hasil penelitian ini sejalan dengan penelitian yang dilakukan oleh Andriana, yang mengemukakan bahwa sebagian besar responden menggunakan kosmetik yaitu sebanyak $54,3 \%$. Jenis kosmetik yang banyak digunakan oleh responden adalah krim pagi dan krim malam. Berdasarkan penelitian yang dilakukan oleh Andriana, didapatkan bahwa sebagian besar responden menggunakan kosmetik jenis bedak tabur. Hasil penelitian ini sejalan dengan penelitian yang dilakukan oleh Andriana, yang mengemukakan bahwa terdapat survei pendahuluan peneliti di kampus Jurusan Analisis Kesehatan Poltekkes Kemenkes RI Medan, yang mengemukakan bahwa terdapat banyak mahasiswi yang menggunakan krim pemutih wajah. Dari 6 lokal kelas yang ada didapatkan 25 mahasiswa putri menggunakan krim pemutih wajah dengan rata-rata lama pemakaian pemutih wajah lebih dari enam bulan (Andriana R, Effendi $A$, Berawi KN, 2014).

Hasil uji chi-square analisis pengaruh antara penggunaan kosmetik dengan acne vulgaris pada remaja putri SMA Negeri 4 Banda Aceh diperoleh $p<0.017$ dengan signifikan 0,05. Hasil ini menunjukan bahwa terdapat adanya pengaruh antara penggunaan kosmetik dengan acne vulgaris. Hasil penelitian ini sejalan dengan penelitian yang telah dilakukan oleh Andriana, yang mengemukakan bahwa terdapat adanya hubungan signifikan antara penggunaan kosmetik dengan kejadian acne vulgaris pada mahasiswi fakultas kedokteran universitas lampung, dengan hasil didapatkan sebanyak 125 responden yang menggunakan kosmetik mengalami akne vulgaris. Hasil penelitian ini tidak sejalan dengan hasil penelitian yang dilakukan oleh Sehat Kabau (2012) di Fakultas Ekonomi Universitas Diponegoro Semarang yaitu tidak terdapat hubungan yang bermakna antara pemakaian kosmetik dengan acne vulgaris $(\rho=0,204)$ dengan responden sebanyak 100 mahasiswi (Kabau S, 2012).

Kosmetik mengandung berbagai bahan campuran antara bahan dasar seperti lemak, air, dan alkohol, serta bahan aktif seperti vitamin, protein dan enzim. Bahan-bahan tersebut akan menyebabkan meningkatnya produksi sebum dan hiperkeratinisasi dari duktus polisebaseus, sehingga mikroorganisme penyebab acne vulgaris seperti propionilbacterium acnes, staphylococcus dermis dan pityrosporum ovale berkembang dan membentuk enzim lipolitik dan menghasilkan komponen aktif seperti lipase, protease, hialuronidase, dan faktor kemotaktik yang akan menimbulkan acne vulgaris dan reaksi inflamasi pada acne vulgaris. Penggunaan kosmetik yang salah seperti tidak sesuai dengan jenis kulit dan menggunakan kosmetik yang mengandung bahan berbahaya seperti pada produk kosmetik pemutih dapat juga menyebabkan timbulnya kejadian acne vulgaris, untuk itu perlu diperhatikan kebersihan wajah dan menggunakan kosmetik dengan bahan yang aman (Andriana R, Effendi A, Berawi KN, 2014).

\section{KESIMPULAN}

Kesimpulan dari penelitian ini 
didapatkan 180 siswi SMA Negeri 4 Banda Aceh sebagai responden dengan penggunaan kosmetik sebanyak 143 siswi yang menggunakan kosmetik, sedangkan 37 siswi lagi tidak menggunakan kosmetik. Terdapat 180 siswi SMA Negeri 4 Banda Aceh sebagai responden dari klasifikasi acne vulgaris sebanyak 71 siswi dengan acne vulgaris ringan, 55 siswi dengan acne vulgaris sedang dan 54 siswi dengan acne vulgaris berat.Terdapat nya pengaruh antara penggunaan kosmetik terhadap acne vulgaris pada remaja putri SMA Negeri 4 Banda Aceh.

\section{SARAN}

Berdasarkan hasil dan kesimpulan penelitian diatas, maka peneliti mencoba memberikan saran saran ataupun masukan, yakni sebagai berikut: Diharapkan kepada pihak SMAN 4 Banda aceh dan instansi kesehatan untuk bekerjasama melakukan penyuluhan atau edukasi mengenai acne vulgaris dan bahanbahan berbahaya pada kosmetik, agar menghindari kejadian acne vulgaris. Diharapkan kepada remaja putri untuk lebih memilih produk kosmetik yang sesuai dengan jenis kulit serta mengandung bahan yang aman seperti bahan-bahan alami. Peneliti selanjutnya diharapkan dapat mengembangkan penelitian lanjutan mengingat keterbatasan waktu pada penelitian ini dan mempertimbangkan faktor-faktor lain yang mempengaruhi penggunaan kosmetik dan kejadian acne vulgaris.

\section{DAFTAR PUSTAKA}

Andriana R, Effendi A, Berawi KN. (2014). Hubungan antara Penggunaan Kosmetik Wajah Terhadap Kejadian Akne Vulgaris pada Mahasiswi Fakultas Kedokteran Universitas Lampung. Medical journal of Lampung University, 3(1):1-8.

Ahmed S, Ahmed I. (2013). Frequency and magnitude of anxiety and depression among acne patients: a study of 100 cases.
Baumann L, Keri J. Acne (Type 1 sensitive skin). In : Baumann L, Saghari S, Weisberg E, eds. Cosmetic dermatology principles and practice. 2 nd ed. New York: Mc Graw Hill; 2010. 121-7.

Cuncliffe WJ, Perera DH, Thackeray $P$, Williams $M$, Froster RA and Williams SM. (2010). Pilo Sebaceuous duct physiology, observation on the number and size of pilo sebaceuous duct in acne vulgaris. But J Dermatol. 95 : 153-5.

Fulton, James JR. (2010). Acne vulgaris. Cited June 21,8 screen in MedscapeJournal. Avalaible from:

http://dermatology.cdlib.org/93/c ommentary/acne/hanna.html.

Harahap M. (2010). Ilmu Penyakit Kulit. Jakarta: Hipocrates. p. 3545.

Harper JC. Acne Vulgaris. Available from: eMedicine Specialities USA. Januari: 2012.

Hartadi. (2012). Dermatosis Non Bakterial. Semarang: Badan Penerbit UNDIP. p.98-105.

Kabau S. (2012) Program Pendidikan Sarjana Kedokteran Universitas Diponegoro Tahun 2012. p.1-18.

NB Simpson, Cuncliffe WJ. (2012). Disorders of sebaceous glands. In: Burns T, Breathnach S, Cox N, Griffiths C, editor. Rook's Textbook of Dermatology, 7 th ed 2012.,Oxford: Blackwell publishing; .p. 43.1-43.75.

Simon C. (2012). Acne vulgaris. Oxford: Oxford University Press.

Susanto SD. (2010). Epidemiologi Akne. Dalam : Seminar and workshop penanganan akne. Semarang, 21-22 Maret 2010. 